\title{
Assessing State Influence on Land Accessibility and Successful Implementation of Federal Government Building Construction Projects in South-South Nigeria (2006-2016)
}

\author{
Rose Chinyere Okoro and Joseph Ugochukwu Ogbuefi
}

\section{ABSTRACT}

Despite the provisions of the Land Use Act (LUA), cap L5 of 2004, to make land available for all stake holders, Federal Government has continuously found it difficult to access land in the states for her developmental projects. Does this influence successful implementation of her building construction projects in south-south Nigeria significantly? To what extent does the State where the project is domiciled influence successful project implementation? In order to provide answers to these questions a survey approach was used in three States (Akwa Ibom, Bayelsa and Cross River), randomly selected with two projects in each State. Structured questionnaire was used to elicit data from screened 179 respondents for the study. Two hypotheses were formulated to guide the research work. The dependent variables studied were land accessibility and successful project implementation while the State where the projects were domiciled was the independent variable. The analytical tools used included simple percentages, one-way Analysis of Variance (ANOVA) and Least Significant Difference (LSD) test. The hypotheses were tested at $\mathbf{. 0 5}$ level of significance. Findings revealed that State where the projects were domiciled had significant influence on the two dependent variables of land accessibility and successful project implementation and that Cross River State was significantly different from the other States on land accessibility but only on Akwa Ibom State on successful project implementation. The research proffers that for land to be easily accessible for Federal Government projects, Federal Government should enshrine in the Nigerian operating Land Policy the customs, traditions, and beliefs of the locals, take centre stage in all levels of land administration and educate her land administrative personnel in respect of government rights in land matters.

Keywords: successful project implementation, land accessibility, indigenous people, Land Use Act (LUA), Federal Government Construction Projects and South-south Nigeria.

\section{INTRODUCTION}

One of the major reasons for the Nigerian Land Nationalization was for ease of land acquisition either for private individuals, company, government, or quasi government for project developmental purposes. To achieve this, the Act makes the following provisions:

Section 28 (3)a and b; Section 28 (4) b "where land is required by Federal Government for public purposes, the (military) Governor may revoke the right of occupancy on the affected land". Section 28 (4) permits the government to revoke right of occupancy for overriding.

Public interest and mining purpose or oil pipelines or any purpose connected therewith. The effectiveness of the practicability of these provisions leaves much to be desired. With the nationalization of Nigerian land by the Land Use Act (LUA), No. 6 of 1978, now cap L5 of 2004 [1], many problems emerge in the event of accessing land for federal government building project implementation in the states. Zero Draft National Land Policy [2] reports that some 40
Published Online: January 7, 2021

ISSN: $2684-446 \mathrm{X}$

DOI : 10.24018/ejgeo.2020.2.1.82

Rose Chinyere Okoro*

Cross River University of Technology, CRUTECH, Calabar, Nigeria.

(e-mail: roseokoro97@gmail.com)

Joseph Ugochukwu Ogbuefi

University of Nigeria Nsukka, Enugu

Campus, Nigeria.

(e-mail: Joseph.ogbuefi@ ${ }^{\circledR}$ nun.edu.ng)

*Corresponding Author years after the promulgation of the Act, the laudable objectives of the Act in making land available for Nigerians (including the federal government) is not realizable. Several factors, arising from the operation of the LUA account for this, including delay in granting of consent by State Governors, exorbitant processing costs, deliberate refusal to release land to "opposition" political parties in the states, non-composition of the Land Use and Allocation Committee (LUAC) in the states, fraudulent practices of appropriating public land for personal and close associates businesses by state governors [2], prolonged court cases for compensation, non-reliability of Land Information System (LIS, GIS) on land titling, activities of powerful cartel on land matters to hinder government developmental strides, fraudulent representation by government land officers in compensation negotiations, revocation of already allocated lands for federal government projects by the state governors, multiple land claimants and pluralism of legislation (indigenous land law operating side by side the LUA) [3]. The forces of these factors differ from State to 
State thereby dictating the pace by which the Federal Government accesses land in the States for her projects. These factors and many others can have significant influence on land accessibility and successful project implementation.

Projects implementation success criteria are time, budget, and technical quality standard. About $80 \%$ of government projects globally, are usually completed beyond scheduled date or abandoned out rightly [4]-[6], culminating to project's time-overrun which will result to budget-overrun thereby making any envisaged benefits from such projects unachievable. Several factors usually account for this including: factors related to the project itself, the project manager/his team members, the Organization (owners of the project) and the external environment, including political, physical, economic, social, and administrative environments of the project [7]-[15]. No study has been done on access to land being a possible critical success/failure factor in public building project implementation, irrespective of the numerous problems associated with it as mentioned above. The problem of land accessibility assumes different magnitudes in different states therefore this research is a pioneer study in this specific area and is undertaken to assess the influence of the State where the project is domiciled on access to land and successful implementation of Federal Government building construction projects in South-South Nigeria for the period between 2006 and 2016.

The aim of the study is to examine the influence of the State where the project is domiciled on land accessibility and successful project implementation of Federal Government construction projects in south-south Nigeria (2006-2016), while the study objective is to determine if land accessibility and successful implementation of Federal Government projects differ significantly among states in South-South Nigeria.

The study area comprises the capital cities of three, (Akwa Ibom, Bayelsa and Cross River), out of six states making up the South-South geopolitical region of Nigeria [16]. The cities are Uyo, Bayelsa and Calabar respectively.

\section{THEORETICAL FRAMEWORK AND LITERATURE REVIEW}

\section{A. Land Nationalization (State Sovereignty over Land)}

Land Nationalization is simply the process of transforming private land into public land by bringing them under the ownership of a national government or a state [17]-[19]. Nationalization may occur without compensation to the original owners. It is at variance with socialization, privatization, and redistribution in the sense that the government retains the ownership, control and management of land and gives use rights to individuals, families, and communities. Land nationalization forbids sale, alienation, and transfer by any other means, and mortgages of land.

Several countries of the world adopt Land Nationalization wholly or partially in solving the problem of public inaccessibility of land for developmental projects. Under Land Nationalization land is not alienated by those holding the use right without the consent of the custodian of the ownership right (Governor or President or Government) in writing. The same principle transcends customary land ownership [20] and [21]. Use right is given to individual members of the community for all purposes for definite or indefinite durations. The community reserves the right to repossess the land when it is needed for overriding interest of the community, so also is the Government under land Nationalization.

\section{B. Envisaged Benefits/Problems of Land Nationalization (State Sovereignty over Land)}

The benefits of Land Nationalization as put forward by UAC-AfDB-ECA [22], Oluwamotemi [23] and Mabogunje [3] include: easy accessibility to and equal land right for all including investors and indigenes for all purposes, security of land right, curb urban land speculation and ligations, enhance land security even for the poor masses, grant unlimited access and control of land to governments for developments, curb astronomical rise in land prices, stop multiple sales of one plot of land to different individuals at the same time, reduce high cost of compulsorily acquired land for public developments and stem inequality in land ownership among citizens.

Carson [24], ECA [22], Oshio [18], Lasabi [25], and Igbintade and Oyeweso [26], enunciate the problems of land Nationalization.

\section{Land Nationalization in West African Nations and Beyond}

In Nigeria, the LUA vests all lands in each State in the respective State governors (and NOT in the President) to hold such in trust for the Nigerian people. By Liberian 1850 law, land is majorly the property of the state [22]. The Land Nationalization Act No. 75 of 1953 (last amended No.49 of 1957 [27]) places the ownership, control, and management of all agricultural land in Union of Burma in their President. Article 40(3) of Ethiopian Proclamation 1/1995 mentioned in Ambaye, Ogbonna and Kaduru [28] declared all rural and urban land as the property of the State and the Ethiopian people, vesting its ownership of urban land in the president and the management of rural land in the Regional Governors. In Benin and Guinea Bissau, land is nationalized with ownership right vested in the state, while use rights are given to individuals. In many of the Francophone countries, land is controlled by the State while private grants of ownership rights are given to individuals for private developments through the process of "immatriculation" [29]. The State also retains and exercises the power of expropriation over land so granted for public interest [30]. In the Anglophone countries, the state has access to land through exercising her power of eminent domain. In Nigeria, the Land Use Act of 1990 is a replica of the northern Nigeria Land Tenure Law of 1962 and the state Law of 1915 applied earlier on in Ghana as the Ghanaian Land and Native Rights Ordinance of 1931 which vested all lands in the northern part of Ghana in the colonial administration in trust for all Ghanaians [22]. In Burkina Faso their 1984 Agrarian Land Reform established a national domain over the entire national territory [22].

\section{Project Defined}

A Project is defined by the Project Management Institution (PMI) Guide of the United States of America as 
"a temporary endeavor undertaken to create a unique product or service" [31].

Cleland [32], UNIDO [33] and Baum and Tolbert [34] give the definitions of Project to be a one-time endeavor which has a definite starting date with unique characteristics. Public developmental projects are usually undertaken for social or political reasons. Ogbuefi [35] advises that in appraising public-sector projects before execution social related matters should be taken into serious consideration. These include socio-cultural norms, beliefs, customs, and subsistence of the people thereby guaranteeing or otherwise of the acceptability of the intending projects by the host community. This thought is echoed by Amade, Ubani, Omajeand Njolu [4], Belassiand Tukel [12], Goodman [36] and Ramlee et al [37]. On the feasibility and viability sides, the authors advocate that the variables that must be studied are varied and include physical variables availability and suitability of appropriate site in good location and possibility for future expansion. The site characteristics should include soil texture, water contents, water table levels, fauna and flora, climatic conditions, geographical layout (topography), the population of the local dwellers, their occupation, reception of the intending project by the locals, the ease of and cost of procuring the site, the envisaged acquisition costs are to be examined [35] and [36].

It should be noted that site availability is the starting point of any project and except this indicator is procured no project can start. The verification of site indicators can be made easier if there is good geographical information of the neighborhood [38].

\section{E. Project Success/Failure - What is it?}

Generally, a project is termed successful if it satisfies stakeholders groups, meets functional requirements, meets quality expectations and requirements, within costs, within deadline, delivers sustained and actual benefits and provides the team with professional satisfaction and learning [39]. A project fails when all the success points are unmet.

There can be an ambiguity in judging whether a particular project is a success or a failure. The reason for this is because the stakeholders to any particular projects are many and their yardsticks for appraising a project's success or failure are also different [12]. The most basic criteria for measuring a project success are cost, time, and performance goals [40], [41] but currently there is a shift in this paradigm. The reason for this shift is because in practice projects schedules are prone to being delayed for one reason or the other [12]. In the construction project field four basic success criteria had long been established. These bother on completion of projects on time, within predetermined budget (cost) and meeting quality or technical performance which satisfy top management, clients, and end users [37], [4]. To achieve the success criteria of project there are some factors that are critical, and they are x-rayed subsequently.

\section{F. What is Critical Success/Failure Factors (CSFFs) in Project Implementation?}

The term critical success factors in project management arena first used by Rockart [42], are those factors which are capable of predicting the success or failure of a project [43] quoted in [4]. Summarily critical success factors in construction projects are those factors which the Project Manager (PM) must identify and monitor closely in order to achieve the success criteria of the envisaged project [44], [15] and [42].

\section{G. CSFFs in Public Construction Project Management}

The variables under this broad framework which contribute immensely to success or failure in public construction project implementation include a strong monitoring and evaluation system [15], [43] and [45], effective communication management [46] effective project scheduling and budgeting, adequate team selection, training, development and motivation, project manager's competence and decision making skills [47] and [48]. Adequate planning [14] and [13], procurement related factors [43] and [49], external factors [12], [50] and [51], realistic estimates of schedules and costs [52] and [53], project stake holders related factors [54] and [55].

Other factors raised in other authors' works are contractor's ability to manage the design [56], [45], provision of adequate finance by the client [54], [57], and leadership skill of the Project Manager [12], [48].

In a concluded study by Amade, Ubani, Omaje, Njolu, [4] during when sixteen variables (critical success factors were analyzed, seven components factors were adjudged critical for successful public sector construction projects. These include efficient and effective procurement process/method, effective communication management, adequate planning, and leadership skill of the project manager, weather conditions, and effective co-ordination of project activities.

Belassi and Tukel [12] critical success factors are grouped to show their interrelationship and cause-effect. They opine that most critical success factors in construction projects are those related to the environment such as economic and weather, followed by the Project Manager's related factors such as co-ordination and competence, next to it being project team members' related factors such as technical background and commitment. Again, they postulate that when time is used as the criteria for measuring project success the critical factor is the project manager's skills and communication between the team members. If quality is the measuring criteria, they offer that this can be achieved by identifying and eliminating factors that cause poor project performance.

\section{H. The Criticality of Land to Public Project Implementation}

It is noteworthy that all that man needs for his existence come from land, he is originally created from its components. Kingdoms fall or rise based on their access to and proper utilization of land resources in their disposal. The Asian Tigers (Japan, South Korea, China, and Taiwan) thrived economically and were reckoned in the first half of the $20^{\text {th }}$ century as the world fastest growing economies because they could manage their land resources successfully [58]. East Timor in Southern Asia was in crisis economically because of its chaotic land tenure arrangements occasioned by its government corrupt practices regarding land matters [24]. Zimbabweans suffered untold economic hardships due to its Prime 
Minister, Robert Mugabe's style of redistributing the nations acquired lands amongst his kit and kin to the detriment of the poor landless of Zimbabwe [24]. In Uganda, out of the 18 documented projects of Uganda National Road Authority (UNRA), as at 2015/16 financial year, it was discovered that the $51 \mathrm{~km}$ Kampala-Entebe Expressway valued at $\$ 479$ gulped the highest land acquisition bill of $\$ 10 \mathrm{ml}$. A claimant who has a stone quarry in a land area of 10 acres demanded $\$ 14$ million as against a valuation figure of $\$ 1.1$ million issued by the chief government valuer. This problem delayed the execution of the civil works in some sections of the road for months and the UNRA officials diverted the road project from the costly land to a cheaper land along the project route [59]. A $17 \mathrm{~km}$, second phase Kampala northern bypass valued at $\$ 75.7$ million, cost $\$ 5.2$ million in cost of land acquisition by close of 2015/16. The $104 \mathrm{~km}$ Mubende-Kakumiro-Kagadi road valued at $\$ 141.6$ million gulped $\$ 2.9 \mathrm{ml}$ in land compensation. It was delayed over disagreement about valuation figures by claimants. Land is needed by the different tiers of government for construction projects. Its inaccessibility spells doom in different dimensions to nations' developmental projects.

\section{MATERIALS AND METHODS}

A survey case study approach, in three randomly selected states (Akwa Ibom, Bayelsa and Cross River) out of the six south-south Nigerian states was adopted. Two projects were randomly selected in each of the three states (Yenagoa in Bayelsa and Calabar in Cross River. The projects studied included: Mbierebe Ibesikpo site and service scheme and New Housing scheme at Ikot Ntuen Nsit/Afia Nsit, north west of Uyo metropolis, FHA estate in Odukpani and New Housing scheme in Ikot Ekpo, north east of Calabar Municipality of Cross River state and New housing scheme at Otuoke located outside the state capital and the Federal Secretariat project located at Swali in Yenagoa) for study covering the study period (2006-2016). This involves a case study of the independent (State) as well as the dependent variables (Land accessibility and successful project implementation) over a period of 10 years. The population of the study was 213 personnel consisting of state Controllers of the Federal Ministries of Power, Works and Housing in the states studied, the directors and/or heads of different units in the Ministry including theirin-house Architects, Quantity Surveyors, Land Surveyors, Estate Surveyors and Valuers, Civil Engineers, Electrical Engineers, Urban and Regional Planners and other departmental staff, all levels of construction contractors and residents of one of the partially completed projects. The Ministry staff double as the state-level government project managing team with Controller-Architect at the apex of the team. For the 2016 New National Housing scheme, there was a 5-man consortium Project Management monitoring team from Abuja. Since the study population has different characteristics, they were stratified, sampled, and drawn for study Osuala [60] as shown in Table I below.
TABLE I: STUDY SAMPLE

\begin{tabular}{|c|c|c|c|}
\hline S/No. & Stratum & Population & $\begin{array}{c}\text { Sample } \\
\text { size }\end{array}$ \\
\hline 1 & $\begin{array}{l}\text { Stratum 1 } \\
\text { Ministry staff: } \\
\text { Project Supervisor/Managers } \\
\text { (architects, Quantity surveyors, } \\
\text { land surveyors and team } \\
\text { members in the state Ministry } \\
\text { of the three states including } \\
\text { members of the Abuja } \\
\text { monitoring Consortium Project }\end{array}$ & $\begin{array}{l}46 \text { (all states } \\
\text { inclusive of 5-man } \\
\text { consortium) }\end{array}$ & 51 \\
\hline 2 & $\begin{array}{l}\text { Stratum } 2 \\
\text { Contractors and sub- } \\
\text { contractors } \\
\text { Stratum } 3\end{array}$ & $\begin{array}{l}82 \text { - (all states and } \\
\text { all projects } \\
\text { inclusive) }\end{array}$ & $53 *$ \\
\hline 3 & $\begin{array}{l}\text { Residents of FHA Estate, } \\
\text { Odukpani, Calabar } \\
\text { Total }\end{array}$ & 80 end users & 80 \\
\hline \multicolumn{4}{|c|}{$\begin{array}{l}\text { *These are all the contractors who actually reported for and took up the } \\
\text { project works. The analytical tool used was one-way ANOVA which } \\
\text { adopted F-distribution statistical test at } 0.5 \text { level of significant which is an } \\
\text { extension of the student t-test which measures the means of two } \\
\text { populations [61]. One-way ANOVA was used to analyze the influence of } \\
\text { location (State) (independent variable) on land accessibility and successful } \\
\text { project implementation of the federal government projects studied. }\end{array}$} \\
\hline
\end{tabular}

\section{A. Data Presentation and Analysis}

Table II tells a simple story: land is available but not easily accessible for project implementation. Aggregately, $71 \%$ of the respondents held that the project sites were not successfully and timely acquired to make room for the commencement of project implementation. 29\% say the sites were successfully and timely acquired. From the table the sites which were successfully acquired are shown to be those of the ongoing New National Housing scheme across the nation. Field investigation revealed that state governments were given timeline to make land available, failing which the states would forfeit the projects. What most governors did was to take already acquired un-utilized land and donated such for the implementation of the project (Akwa Ibom, Bayelsa, and Cross River FHA projects). Even at that, entries into the already acquired lands were reported to still be problematic due to fresh demands by the locals.

TABLE II: SuCCESSFul/Timely ACQuisition of PROJECT SiTES By STATE

\begin{tabular}{|c|c|c|c|c|c|}
\hline \multirow[t]{2}{*}{ State } & \multirow[t]{2}{*}{ Project sites } & \multicolumn{4}{|c|}{$\begin{array}{l}\text { Timely/successful acquisition } \\
\text { of site }\end{array}$} \\
\hline & & Yes & $\%$ & No & $\%$ \\
\hline Akwa & $\begin{array}{l}\text { Mbierebe Obio site/service } \\
\text { scheme }\end{array}$ & - & 0 & 35 & 100 \\
\hline Ibom & 2016 New Housing scheme & 20 & 54.1 & 15 & 45.9 \\
\hline Bavelsa & Fed. Secretariat Complex & - & 0 & 13 & 100 \\
\hline Bayelsa & 2016 New Housing scheme & 13 & 100 & - & 0 \\
\hline Cross & $\begin{array}{l}\text { Fed. Housing Authority } \\
\text { Res. Estate }\end{array}$ & 70 & 63.1 & 61 & 36.9 \\
\hline River & $\begin{array}{l}2016 \text { New Housing } \\
\text { Scheme }\end{array}$ & - & 0 & 131 & 100 \\
\hline Total & & 103 & 29 & 255 & 71 \\
\hline
\end{tabular}

\section{B. The research Hypotheses}

$\mathrm{HO}_{1}$ : State has no significant influence on land accessibility

and

$\mathrm{HO}_{2}$ : State has no significant influence on successful implementation of the projects studied.

To test these hypotheses, one-way analysis of variance (ANOVA) was adopted with State, where the projects are domiciled, as factor (independent variable) and land 
accessibility and successful implementation of Federal government project construction projects as dependent variables. The descriptive statistics of the dependent variables by States, are presented in Table III below.

From the above results in Table 3 and in respect of land accessibility, Bayelsa state had the highest mean $(\mathrm{x}=11.31)$, followed by Akwa Ibom state (10.49) before Cross River state with the least mean of (8.39). With respect to Successful implementation of projects, Akwa Ibom had the highest mean (18.51), followed by Bayelsa state (17.69) while least was Cross River state $(\mathrm{x}=15.11)$.

The ANOVA Table 4 presents the results of the test of significance differences between states. The results as presented in Table 4 above indicate that the P-values (.006 and .002) of the dependent variables associated with their computed F-values (5.341, and 6.718) are all less than the alpha value (.05), the level of significant, set for the study. Hence, the null hypothesis was rejected, and the alternative retained. This means that the States where the different projects are located have significant influence on land accessibility, and successful implementation of the Federal Government construction projects studied.

To identify the pair of means that was responsible for the observed significant results, the Least Significant Difference (LSD) test was computed. The results are presented in Table 5 below.

The results of Table V show that for land accessibility, Cross River State is significantly different from other states. However, for successful implementation of projects studied, Cross River is significantly different from only Akwa Ibom State.

\begin{tabular}{cccccccc}
\multicolumn{7}{c}{ TABLE III: DESCRIPTIVE STATISTICS OF VARIABLES (DEPENDENT) BY STATE } \\
\hline \multirow{2}{*}{ Variable } & State & $\mathrm{N}$ & Mean & $\begin{array}{c}\text { Std. } \\
\text { dev. }\end{array}$ & $\begin{array}{c}\text { Std. } \\
\text { error }\end{array}$ & Minimum & Maximum \\
\hline & Akwa Ibom & 35 & 10.49 & 3.023 & 0.511 & 3 & 15 \\
Land accessibility & Bayelsa & 13 & 11.31 & 2.529 & 0.702 & 6 & 15 \\
& Cross River & 131 & 8.39 & 4.675 & 0.407 & 3 & 15 \\
& Total & 179 & 9.01 & 4.388 & .327 & 3 & 15 \\
Successful Project & Akwa Ibom & 35 & 18.51 & 5.404 & 0.913 & 5 & 25 \\
Implementation & Bayelsa & 13 & 17.69 & 4.270 & 1.184 & 13 & 25 \\
& Cross River & 131 & 15.11 & 5.227 & 0.455 & 5 & 25 \\
& Total & 179 & 15.96 & 5.366 & 0.400 & 5 & 25 \\
\hline
\end{tabular}

TABLE IV: ONE-WAY ANOVA OF DEPENDENT VARIABLES: LAND ACCESSIBILITY, AND SUCCESSFUL PROJECT IMPLEMENTATION OF FEDERAL GOVT.

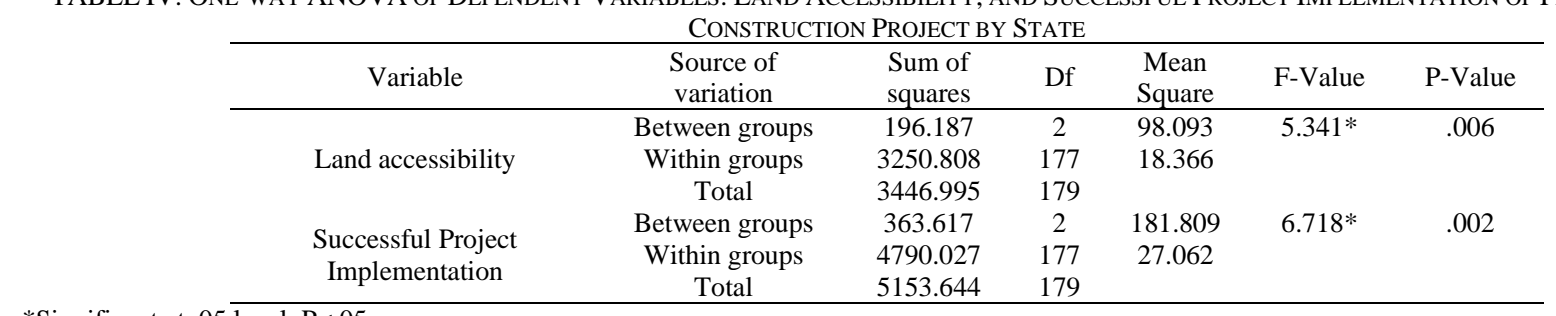

*Significant at .05 level. $\mathrm{P}<.05$.

TABLE V: PAIR Wise COMPARISON OF THE DEPENDENT VARIABLES - LAND ACCESSiBILITy AND SUCCESSFUl PROJECT IMPLEMENTATION OF FEDERAL GOVERNMENT BY STATE

\begin{tabular}{|c|c|c|c|c|}
\hline Variable & State & $\begin{array}{l}\text { Akwa } \\
\text { Ibom }\end{array}$ & Bayelsa & $\begin{array}{l}\text { Cross } \\
\text { River }\end{array}$ \\
\hline \multirow{3}{*}{ Land accessibility } & Akwa Ibom & $10.49 * *$ & .822 & $2.099 *$ \\
\hline & Bayelsa & .556 & 11.31 & $2.921^{*}$ \\
\hline & Cross River & .011 & .020 & 8.39 \\
\hline \multirow{3}{*}{$\begin{array}{l}\text { Successful Project } \\
\text { Implementation }\end{array}$} & Akwa Ibom & $18.51 * *$ & .822 & $3.408 *$ \\
\hline & Bayelsa & .627 & 17.69 & 2.586 \\
\hline & Cross River & .001 & .089 & 15.11 \\
\hline
\end{tabular}

*Significant at .05 level. $\mathrm{P}<.05$. **values along main diagonal are States' means, above it (the diagonal) is States' mean differences and below it (the diagonal) is corresponding $\mathrm{P}$-values.

\section{DISCUSSION OF FINDINGS}

\section{A. The study Hypotheses $\left(\mathrm{HO}_{1}\right.$ and $\left.\mathrm{HO}_{2}\right)$}

The tests of Hypotheses one and two was to discover whether the State where the projects are located had any significant influence on the dependent variables of land accessibility and successful project implementation of the projects studied.

The results showed that States where the different projects were domiciled had significant influence on land accessibility and successful project implementation. In relation to land accessibility [22], [23], [3], [1] and [35] for the projects studied, it was easiest to access land in Bayelsa, followed by Akwa Ibom and most difficult to gain access to land in Cross River state. For successful implementation
[40], [41] and [37] of the projects studied, Akwa Ibom State came first in project time, quality standard and predetermined project budget [12]. This is because for the 2016 National Housing scheme, the Consortium Project Monitoring Team kept track of the project implementation, making sure the quality standard in workmanship, materials, equipment was strictly adhered to [12]. It was common place to see poorly constructed portions of the structures pulled down and subsequent qualitative ones constructed in strict adherence to pre-determined standard. This was possible because they had quiet possession of the site, void of disturbances from the locals [35] and [36]. Machines were also mounted on site for block molding using specified grade of sands and other materials. Project timetable ([37], [4] and [59]) was exceeded but not as other 
States - Cross River and Bayelsa. Following Akwa Ibom was Bayelsa State. Cross River came last in successful project implementation due to land accessibility and acquisition problems [2]. For the FHA housing project, the supervising engineer was operating from Abuja and was scarcely seen on site [15], [43] and [12]. The person whom he asked to stand in for him was not forthcoming. The result of the non-monitoring is seen in structural cracks on the walls of almost all the completed buildings on site (see pictures in appendix please). Majority of the buildings are standing in pools of water during the rains and cannot be accessed [35]. For the 2016 National Housing scheme, the disturbances of the indigenous people made it impracticable for the 5-man monitoring team/ the in-house team from the State Federal Ministry to enter site and monitor the contractors. The indigenes insist on supplying any substandard materials for the buildings and they were allowed to in order to allow the contractors have access and carry out their works undisturbed [35] and [36]. In the whole quality standard was compromised in labor, construction, materials, and equipment.

Following from the initial results of testing this hypothesis, the Least Significant Difference (LSD) was carried out to locate the pair of means that was responsible for the observed significant result in the test. The results, as mentioned earlier, are presented in Table 5 above. In land accessibility, Cross River State is significantly different from Akwa Ibom State (.011) and Bayelsa State (.020), but for Successful project implementation Cross River is only significantly different from Akwa Ibom State (.001). It is different from Bayelsa but not significantly. Summarily from the test result, it is discovered that Cross River State had the greatest problem in relation to access to land, which had a reprisal influence on successful project implementation.

\section{CONCLUSION FROM THE FINDINGS}

On the basis of the findings, it can be concluded that Cross River posed greatest problem in land accessibility and successful projects implementation of Federal Government projects located in the State. The State was significantly different from Akwa Ibom and Bayelsa in relation to land accessibility, whereas on Successful project implementation it was only significantly different from Akwa Ibom State. This difference was majorly due to continuous problems over land related issues caused by the community youths in Ikot Omin of Cross River State where one of the two projects was located.

\section{REFERENCES}

[1] Federal Republic of Nigeria. (2004). Land Use Act No. 6 of 1978 now (Land Use Act Cap L.5 2004 LFN.

[2] Zero Draft National Land Policy. (2014). Zero Draft National Land Policy. ABUJA: MABUSHI.

[3] Mabogunje, A. (n.d). Land Reform in Nigeria: Progress, Problems and Prospect. Lagos.

[4] Amade, B., Ubani, E. C., Omajeh, E. O.-M., \&Njolu, U. P. (2015). Critical Success Factors for public sector construction project delivery - A case of Owerri, Imo state. International Journal of Research in Management, Science \& Technology, 3 (1), 2321-3264.
[5] Okott, E. (2016, November 22). Daily nation. Retrieved February 19, 2017, from Daily nation web site: http:www.nation.co.ke.

[6] Anyannzwa, J. (2016, September 4). Changes to Kenya's Land Law to Tame Cost of Public Projects and Developments. Retrieved March 11, 2017, from http:wwwtheeastafrican.co.ke>news $>2558$.

[7] Pinto, J. K., \& Slevin, D. P. (1988). Project Success: Definition and Measurement techniques. Project Management Journal, XIX (1), 6772.

[8] Martin, C. (1996). Project Management. New York: Amaco.

[9] Locke, D. (1984). Project Management. New York: St. Martins Press.

[10] Cleland, D. I., \& King, W. R. (1983). Systems Analysis and Project Management. New York: McGraw Hill.

[11] Morris, P., \& Hough, G. H. (1987). The Anatomy of Major Projects. A study of the reality of Project Management. Chichester: John Willey \& Sons.

[12] Belassi, W., \&Tukel, O. I. (1996). A new framework for determining critical success/failure factors in projects. International Journal of Project Management, 14 (3), 141-151.

[13] Akpan, E., \& Igwe, O. A. (2001). A methodology for determining Price variation in Project Execution. Journal of Construction and Management of the American Society of Civil Engineers ASCE), 127 (5), 367-373.

[14] Haughey, D. (2014). Eight Key Factors to Ensuring Project Success. Project Smart.

[15] Alinaitwe, H., \& Ayesiga, R. (2013). Success factors for the implementation of Public-Private Partnership in the Construction Industry in Uganda". Journal of Construction in Developing Countries, 18 (2), 1-14.

[16] Nairaland. (2015, June 15). South-south Region Guide. PoliticsNigeria-Nairaland. Retrieved December 12, 2016, from Nairaland website: http://www.nairaland. com>south-south-region.

[17] Wallace, R. (1892). Land Nationalization- Personal/Profession/People. Retrieved Nov. 15, 2016, from Charles Smith Wallace website: http://www.wku.edu>charles.smith>wallace.

[18] Oshio, P. E. (1990). The Indigenous Land Tenure and Nationalization of Land in Nigeria, 10 B.C. Third World Law Journal, 10 (1), 43-62.

[19] Great Soviet Union. (1979). Great Soviet Union Encyclopedia.

[20] Oluyede, P.A. (1978). Nigerian Law of Conveyance. Ibadan, Nigeria: Ibadan Univ. Press, Univ. of Ibadan. 978-121-040-0.

[21] Nwabueze, B. (1972). Nigerian Land Law. ENUGU: NWAMIFE, Oceanic Publications Inc. Dobbs Ferry, New York10522.

[22] AUC-ECA-AfBD. (2011). Land Policy in Africa: West Africa Regional Assessment. Adis Ababa: ECA Publications and Conference Management Section (PCMS).

[23] Oluwamotemi, D. K. (2010). Land Acquisition, Compensation and Resettlement in Developing Economies: Nigeria as a Case Study. Fig. Congress 2010, (pp. 1/9 - 9/9). Sydney, Australia.

[24] Carson, A. (2007). East Timor Land Tenure Problems: A Consideration of Land Reform Programs in South Africa and Zimbabwe. IND.INT'LCOMP. L. REV., 395-430.

[25] Lasabi, B. (2014, March). Governors abuse powers under the Land Use Act. Retrieved July 21, 2014, from Daily Independent web site: http://dailyindependentnig. com/2014/03/governors-abuse-powersunder-land-use-act-lasabi.

[26] Igbintade, \&Oyeweso. (2013, September 26). Land Use Act turns tools of oppression of hapless Nigerians. National Mirror, from http://national mirror online. net/new/land-use-act-turns-tool-ofoppression-of-haplessnigerians.

[27] Union of Burma Government. (1957). The Land Nationalization Act, No. 49.

[28] Ambaye, D. (2012). Land Rights in Ethiopia: Ownership, Equity, and Liberty in Land Use Rights. Being a paper presented in a Conference. FIG Working Week 2012 (pp. 1/27 - 27/27). Rome, Italy: TS02D Customary and Group Land Rights, 5521.

[29] Chauveau, J., Colin, J., Jacob, J., Delville, P., \& and Le Meur, P. (2006). Changes in Land access and governance in West Africa: Markets, Social mediations and Public policies, Resultats du recherche CLAIMS, Londres. LONDON: International Institute for Environment and Development, GRET, IUED and IRD.

[30] Mulugeta, S. (1999). Public Ownership of Urban Land and LowIncome Ownership in Addis Ababa, Ethiopia. EASSRR, XV (1), 79-96.

[31] Project Management Institute. (1996). Project Management Institute. Retrieved February 18, 2017, from Project Management Institute website: http://www.pmi.org.1996.

[32] Cleland, L. C. (1995). Project Management. New York: McGraw Publishers.

[33] UNIDO. (1986). Guide to practical Project Appraisal: SCBA in Developing countries. Viena: UNIDO.

[34] Baum, W., \& Tolbert. (1978, December Issue). The Project Cycle. Finance and Development Journal. 
[35] Ogbuefi, J. U. (2011). Aspects of Feasibility and Viability Studies. Enugu, Nigeria: Institute for Development Studies, Univ.of Nigeria, Enugu Campus.

[36] Goodman, Louis, J.P.E. (1988). Project Planning and Management: An Integrated System for Improving Productivity. New York: VAN NOSTRAND REINHOLD COMPANY Inc.

[37] Ramlee, N., Tammy, N. J., Raja Mohd Noor, R. N., Ainun, A. M., Abdul, N. K., Chan', H. B., (2016). Critical Success factors for construction project. AIP conference Proceedings 1774, 030011 http://dx.doi.org/10.1063/1.4965067. America: American Institute of Physicsh.

[38] Castle, H. B (1998). GIS in real Estate: Integrating Analyzing and Presenting Location Information. Appraisal Institute in association with Adams Business Media/GIS World. United States of America.

[39] Thomsett, R. (2002). Project Pathology, causes, patterns and symptoms of project failure. Retrieved March 14, 2017, from thomsett.com
website: http.//www.thomsett.com.au/main/articles/path/toc.htm.

[40] Greer, M. (1999). Handbook of Human Performance Technology. H. San Francisco: Jossey-Bass.

[41] Shenhar, A., Dvir, D., Levy, O., \& Maltz, A. C. (2001). Project Success: A multidimensional Strategic concept. Journal of Long range planning, 34 (6), 699-725.

[42] Rockart, M. (1982). Factors Affecting Business Growth. New York: Wiley.

[43] Baccarini, D. (2009). "Critical Success Factors in Construction Engineering Projects. A Case Study". AIPM09 Refereed Paper.

[44] Baccarini, D., \& Collins, A. (2003). Critical Success Factors for Projects in Brown, A. (ed), Surfing the Waves: Management Challenges; Management Solutions" Proceedings of the 17th ANZAM Conference. 17th ANZAM Conference. Western Australia: Fremantle.

[45] Ika, L. A., Diallo, A., \& Thuillier, D. (2012). Critical Success Factors for world Bank Projects: An Empirical Investigations. International Journal of Project Management, 105-116.

[46] Omran, A., Abdulbagei, M. A., \& Gebril, A. O. (2012). An Evaluation of the Critical Success Factors for Construction Projects in Lybia. International Journal of Economic Behaviour, 2, 17-25.

[47] Adnan, H., Yusuwan, N. M., Yusuf, F., \& and Bachik, F. (2014). Critical factors for contractors. International Journal for engineering and Technical Research, 2 (2), 107 - 113.

[48] Pinto, J. K., \&Slevin, D. P. (1987). Critical factors in successful project implementation. IEEE Transactions on Engineering Management, EM - 34 (1), 22-27.

[49] Barasa, H. W. (2014). Procurement Practices affecting Effective Public Projects Implementation in Kenya: A Case study of Kenya Civil Aviation Authority. European Journal of Business Management, 6 (6.www.iiste.org), 49-67.

[50] Tan., D. J.-Z. (2011). Critical Success factors for Malaysian Contractors in international construction projects using Analytical Hierachy Process. EPPM, 20-21, 127-138.

[51] Alvani, E., Benjamin, M., \& and Hoseinalipour, M. (2014). Analysis of Critical Success factors in Design-Built Projects: a case study of Karaj Urban Projects. International Journal of Innovative Science, Engineering and Technology, 1 (6).

[52] Nasir, M. H. \& Sahibuddin, S. (2011). Critical Success factors for Software Projects: A Comparative Study. Scientific Research and Essays, 6 (10), 2174-2186.

[53] Omajeh, E. O.-M. (2014). Analysis of factors responsible for Project Cost Underestimation. An unpublished MSc dissertation of the Federal Univ.of Technology, Owerr, Nigeria.

[54] Yong, Y. E., \& Mustaffa, N. E. (2012). Analysis of Factors Critical to Construction Project Success in Malaysia. Engineering Construction and Architectural Management, 19 (5), 1-13.

[55] Dolan, K. (2010). Addressing Project Failure throughPRINCE2. The Stationery Office, White Paper.

[56] Saqib, M., Farooqui, R. U., \& Lodi, S. H. (2008). Assessment of Critical Success Factors for Construction Projects in Pakistan. First International Conference on Construction in Developing Countries (pp. 392-404). Pakistan: Karachi.

[57] Ejaz, N., Hussain, J., Shabbir, F., Shamim, M. A., Naeem, U. A., \& Tahir, M. F. (2013). Assessment of most Critical success factors for mega construction projects in Pakistan. Life Science Journal, 10 (10 www.lifesciencesite.com), 255-261.

[58] Boyce, Rosset, \& Stanton. (2005). Land Reform and Sustainable Development, being a Working Paper series 98. Retrieved 5 2, 2014, from Umas. http:www/umas.edu/peri/programs/development/naturalassets.htm.

[59] Theeastafrican. (2016, September Saturday). theeastafrican.co.ke. Retrieved March 7, 2017, from theeastafrican.co.ke web site: http://www.theeastafrican.co. ke/image/view/-.
[60] Osuala, E. C. (1982). Introduction to Research Methodology. Onitsha: Africana - FEB Publishers Ltd.

[61] Asika, N. (1991). Research Methodology in the Behavioural Sciences. Ikeja, Lagos, Nigeria: Longman Nigeria Ltd.

[62] Bob, C. (2001, February 2). Zimbabwe's Land Reform Still Controversial. Retrieved September 7, 2016, from CNN website: http://archives.cnn.com/WORLD/ Africa/02/09/inside. Africa.

[63] Chapman, C., \& Ward, S. (2003). Project Risk Management. Process, Techniques \& Insights. West Sussex: John Wiley\& Sons Ltd.

[64] Davies, C. T. (2002). The "real" Success factors on Projects. International journal of Project Management, 185 to 190.

[65] Federal Republic of Nigeria (FRN). (1990). Land Use Act (No. 2 of 1990) LFRN.

[66] Federal Republic of Nigeria. (1962). Northern Nigeria Land Tenure Law.

[67] Federal Republic of Nigeria. (1976). Public Land Acquisition (Miscellaneous Provision), Decree No. 33.

[68] Federal Republic of Nigeria. (1958). Public Lands Acquisition (Miscellaneous Provisions Act).

[69] Federal Republic of Nigeria. (1917). Public Lands and Acquisition Act, Cap 167.

[70] Federal Republic of Nigeria. (1968). State Lands (Compensation) Decree.

[71] Federal Republic of Nigeria. State Lands Act. (Cap45).

[72] Government of Nigeria (GoN). (1953). Land and Native Rights Proclaimation 1910.

[73] Land Use Panel. (1977). Report of the Land Use Panel 5. Lagos.

[74] National Population Commission of Nigeria. (2016, 3 21). Akwa Ibom State. Retrieved 9 21, 2018, from National Population Commission of Nigeria: https://www.citypopulation.de/php/nig-admin.php.

[75] National Population Commission of Nigeria. (2016, 3 21). Bayelsa State. Retrieved 9 21, 2018, from National Population Commission of Nigeria: https://www.citypopulation.de/php/nigeria - admin.php.

[76] National Population Commission of Nigeria. (2016, 3 21). Cross River State. Retrieved 9 20, 2018, from National Population Commission of Nigeria: https://www.citypopulation.de/php/nigeria -admin.php.

[77] Nigeria Galleria. (2015). Nigeria Galleria. Retrieved March 29, 2017, from Nigeria Galleria website: http://www.nigeriagalleria.com, Bayelsa state, Nigeria.

[78] Otieno, J. (Oct.3,2015). Kenya proposes law to cap payment for land for compulsory project. Kenya: www.theeastafrican.co.ke.

[79] PMI. (2009, April 2). Project Management Institute. Retrieved February 18, 2017, from Project Management Institute website: http://www.pmtips.net.

[80] Republic of Kenya. (2016). Kenya Gazette Supplement No.149 (Acts No.28). Nairobi: The Govt. Printer.

[81] Union of Burma Government. (1955). The Land Nationalization Act. No. 54.

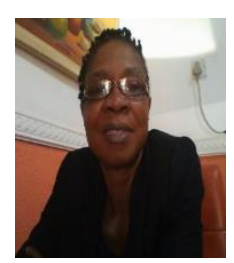

Rose C. Okoro is a Senior Lecturer in the Department of Estate Management Cross River University of Technology, Calabar, with majors in Project Management, Land Appraisal, Valuations and Land Use. She holds an MBA in Project Management from Federal University of Technology, Owerri, MS.c in Estates Management, and $\mathrm{Ph} . \mathrm{D}$ in Estates Management from Abia State University, Uturu. She has published fifteen (15) journal articles locally and internationally. She is presently working on Correlation between Project Risk Management and Achieving Project Objectives in Public Project Execution - 500 units Hostel Complex of CRUTECH, Calabar.

ESV. Dr. (Mrs.) Okoro is a member of Nigerian Institution of Estates Surveyors and Valuers (NIESV), African Real Estate Society (AfRES), American Real Estates Society (ArES). In 2016 she bagged the best HOD Award in her Department.

Professor Joseph U. Ogbuefi is a Professor in the Department of Estates Management, University of Nigeria Nsukka, Enugu Campus with majors in Urban Land Appraisal and Property Taxation. He has authored several books and journal articles. He is a Fellow of Nigerian Institution of Estate Surveyors and Valuers (NIESV), a member of African Real Estates Society (AfRES) and American Real Estates Society (ArES). 